\title{
KEBIJAKAN HUKUM PIDANA CYBERPORNOGRAPHY TERHADAP PERLINDUNGAN KORBAN
}

\author{
Mahsun Ismail \\ Universitas Islam Indonesia, Email : mahsunismail09@gmail.com
}

\begin{abstract}
ABSTRAK
Tindak pidana cybercrime merupakan persoalan yang tidak mudah dalam penegakan hukum maupun perlindungan terhadap korban cyber khususnya dalam tindak pidana cyberpornography. Kebijakan hukum pidana masih berorientasikan terhadap kepentingan pelaku namun kepentingan korban cyberpornography kurang mendapatkan perhatian dari para penegak hukum karena sudah dianggap telah diwakili kepentingannya oleh Negara (jaksa). kebijakan Hasil dari penelitian ini menggambarkan bagaimana pentingnya penerapan asas rights to be forgotten terhadap korban cyberpornography sehingga kepentingan korban untuk terbebas dari stigma negative atas kejadian yang dialaminya.
\end{abstract}

Kata-kata kunci : Kebijakan, perlindungan korban, rights to be forgotten

\begin{abstract}
Crime of cybercrime is a problem that is not easy in law enforcement and protection of victims of cyber, especially in criminal acts of cyberpornography. Criminal law policy is still oriented towards the interests of the perpetrators, but the interests of victims of cyberpornography are not getting the attention of law enforcers because the State (the prosecutor) has assumed its interests. policy The results of this study illustrate how important the application of the principle of rights to be forgotten to victims of cyberpornography so that the interests of victims to be free from negative stigma over the events they experienced.
\end{abstract}

Keywords: Policy, Victim Protection, Rights to be Forgotten

\section{PENDAHULUAN}

Perkembangan dunia teknologi informasi dewasa ini telah membawa manusia kepada era globalisasi yang memberikan ruang kebebasan kepada setiap orang di dunia untuk saling bersosialisasi dan berinteraksi dengan siapapun dan dimanapun mereka berada. Media social termasuk internet merupakan media utama yang dapat digunakan, karena melalui media sosial dan internet seseorang dapat terhubung dengan teman atau bahkan dengan orang asing yang sama sekali tidak dikenal dan berdomisili di luar 
negeri. Kemajuan teknologi informasi dan komunikasi telah melahirkan berbagai dampak, baik dampak positif maupun dampak negatif, karena di satu sisi memberikan kontribusi bagi peningkatan kesejahteraan, kemajuan dan peradaban manusia, namun di sisi lain menjadi sarana efektif melakukan perbuatan melanggar hukum.

Teknologi informasi dan komunikasi juga telah mengubah perilaku dan pola hidup masyarakat secara global, dan menyebabkan dunia menjadi tanpa batas (borderless), serta menimbulkan perubahan di berbagai bidang kehidupan (Raharjo, 2002: 34). Pelbagai persoalan muncul ketika media teknologi informasi dan komunikasi (internet) merubah cara pandang seseorang dalam maksud untuk melakukan kejahatan atau tindak pidana, dari yang sebelumnya dilakukan secara konvensional beralih kepada media intenet untuk melakukan modus operandinya. Seperti halnya kejahatan kesusilaan, perjudian, penghinaan atau pencemaran nama baik, pemerasan atau pengancaman yang sudah diatur dalam KUHP pun juga dilakukan secara konvensional sudah beralih ke media internet untuk melakukan aksi tindak pidana tersebut.

Kejahatan pornografi (cyberporn) merupakan salah satu jenis cyber crime yang meresahkan dan banyak mendapat perhatian.Kejahatan siber (cyber crime) bersifat transnasional atau lintas batas negara membutuhkan suatu penanganan yang khusus, berbeda dengan penanganan kejahatan konvensional (Manurung, 2016: 7). Convention on Cybercrime, Budapest, 23.XI.2001 juga memuat pengaturan yang berkaitan dengan kejahatan pornografi (cyberporn). Convention on Cybercrime 2001 tersebut merupakan regulasi internasional pertama yang mengatur tindak pidana siber dan menjadi pedoman dalam relugasi tindak pidana dalam hukum nasional (Suseno, 2012: 116).

Undang-Undang Nomor 11 Tahun 2008 Tentang Informasi Dan Transaksi Elektronik khususnya Pasal 27 bahwa seseorang dilarang melakukan tindakan-tindakan pendistribusian atau penyebaran, transmisi, dapat diaksesnya konten illegal baik itu kesusilaan, perjudian, penghinaan atau pencemaran, serta pemerasan atau pengancaman. Cybercrime telah menjadi bahya nyata yang merugikan masyarakat dan Negara, setiap penggina computer saat memasuki dunia maya melalui jaringan internet 
sama artinya dengan memposisikan dirinya akan menjadi korban berbagai bentuk informai global yang bersifat menjerat, menyesatkan, menipu dan mengorbankannya (Wahid\&Labib, 2010: 132). Sudah menjadi rahasia umum, bahwa internet dipenuhi dengan infromasi yang kadang kala berlebihan. Salah satu informasi tersebut atau bahkan tidak bisa dibilang informasi adalah materi pornografi. Internet telah menjadi semacam referensi dalam mencari materi yang berbau pornografi. Hal ini cukup sulit untuk dicegah, karena dalam hal ini informasi tersebar tanpa batas di internet. Walaupun masih bisa diberikan peringatan, bahwa suatu situs tidak sepatutnya untuk dikunjungi, tetapi tetap saja bisa dikunjungi (Hidayatullah\&Dharmawan, 2004: 181). Selanjutnya, dari sekian banyak dari tindak pidana yang bersinggungan atau menggunakan dengan media internet, yang cukup menarik dan juga probelmatik adalah penyebaran muatan pornografi melalui internet (cyber pornography). Cyber pornography merupakan perbuatan atau kegiatan yang dilakukan dengan membuat, memasang, mendistribusikan dan menyebarkan nmaterial yang berindikasi pornografi ke media internet. Istilah "cyberpornography" terdiri dari 2 (dua) istilah yang membentuknya yaitu "cyber"(siber) yang berarti sistem komputer dan informasi, berhubungan dengan internet, dan "pornography" (pornografi) yang berarti "penggambaran tingkah laku secara erotis dengan lukisan atau tulisan untuk membangkitkan nafsu birahi"(Depdiknas, 2011: 1301).

Kegiatan cyber pornography tidak hanya bertentangan dengan norma kesusilaan, agama, kesopanan, hukum yang secara jelas akan merugikan dan merusak tatanan moral masyarakat namun lebih dari itu adalah perlindungan bagi korban dari tindakan cyber pornography. Perlindungan hukum maupun secara regulasi peraturan perudang-undangan perlu dilakukan untuk kepentingan korban cyber pornography hal itu mengingat bahwa korban selaku yang dirugikan baik secara materiil dan non-materiil dari tindakan cyber pornography pun juga mendapat perlakuan atau stigma negative dari masyarakat meskipun korban sudah tidak melakukan perbuatan tersebut. Merespon hal itu Pemerintah dan DPR pada tahun 2016 melakukan Perubahan Atas Undang-Undang 11 Tahun 2008 menjadi Undang-Undang Nomor 19 Tahun 2016 tentang Informasi dan Transaksi Elektronik. 


\section{PEMBAHASAN}

\section{Pengertian Kebijakan (policy) dan Kebijakan Hukum Pidana (criminal policy)}

Sebelum dibahas lebih jauh mengenai konsep kebijakan penegakan hukum pidana, maka tentunya perlu mengakaji terlebih dahulu mengenai konsep kebijakan atau dalam bahasa inggris sering kita dengar dengan istilah policy. Dalam Kamus Besar Bahasa Indonesia, kebijakan diartikan sebagai rangkaian konsep dan asas yang menjadi garis besar dan dasar rencana dalam pelaksanaan suatu pekerjaan, kepemimpinan, dan cara bertindak (tentang pemerintahan, organisasi, dsb); pernyataan cita-cita, tujuan, prinsip dan garis pedoman untuk manajemen dalam usaha mencapai sasaran.

Carl J. Federick sebagaimana dikutip Leo Agustino mendefinisikan kebijakan sebagai serangkaian tindakan/kegiatan yang diusulkan seseorang, kelompok atau pemerintah dalam suatu lingkungan tertentu dimana terdapat hambatan-hambatan dan kesempatan-kesempatan terhadap pelaksanaan usulan kebijaksanaan tersebut dalam rangka mencapai tujuan tertentu (Agustino, 2008: 7). Pendapat ini juga menunjukan bahwa ide kebijakan melibatkan perilaku yang memiliki maksud dan tujuan merupakan bagian yang penting dari definisi kebijakan, karena bagaimanapun kebijakan harus menunjukan apa yang sesungguhnya dikerjakan daripada apa yang diusulkan dalam beberapa kegiatan pada suatu masalah. Solichin Abdul Wahab mengemukakan bahwa istilah kebijakan sendiri masih terjadi silang pendapat dan merupakan ajang perdebatan para ahli. Maka untuk memahami istilah kebijakan, Solichin Abdul Wahab (2008: 40-50) memberikan beberapa pedoman sebagai berikut :

a. Kebijakan harus dibedakan dari keputusan;

b. Kebijakan sebenarnya tidak serta merta dapat dibedakan dari administrasi;

c. Kebijakan mencakup perilaku dan harapan-harapan;

d. Kebijakan mencakup ketiadaan tindakan ataupun adanya tindakan;

e. Kebijakan biasanya mempunyai hasil akhir yang akan dicapai;

f. Setiap kebijakan memiliki tujuan atau sasaran tertentu baik 
eksplisit maupun implicit;

g. Kebijakan muncul dari suatu proses yang berlangsung sepanjang waktu;

h. Kebijakan meliputi hubungan-hubungan yang bersifat antar organisasi dan yang bersifat intra organisasi;

i. Kebijakan publik meski tidak ekslusif menyangkut peran kunci lembaga-lembaga pemerintah;

j. Kebijakan itu dirumuskan atau didefinisikan secara subyektif.

Berdasarkan pendapat berbagai ahli tersebut di atas maka dapat disimpulkan bahwa kebijakan adalah tindakan-tindakan atau kegiatan yang sengaja dilakukan atau tidak dilakukan oleh seseorang, suatu kelompok atau pemerintah yang di dalamnya terdapat unsur keputusan berupa upaya pemilihan diantara berbagai alternatif yang ada guna mencapai maksud dan tujuan tertentu. Dalam kaitannya dengan hukum pidana, kebijakan mempunyai peran besar dalam menanggulangi kejahatan yang terjadi di masyarakat yang dikenal dengan istilan kebijakan hukum pidana (criminal policy) yang teraktualisasikan dalam bentuk peraturan perundang-undangan.

\section{Kebijakan Hukum Pidana (criminal policy)}

Penanggulangan kejahatan melalui kebijakan hukum pidana semakin banyak digunakan dan diandalkan dalam rangka mengatur, menertibkan masyarakat melalui peraturan perundang-undangan. Hal itu bisa dilihat dari adanya kebijakan-kebijakan yang dikelurkan oleh pemerintah (negara) dengan menggunakan sanksi pidana melalui pencantuaman bab tentang "ketentuan pidana" pada bagian akhir semua produk perundang-undangan. Hal tersebut tidak mengherankan mengingat kebijakan hukum pidana atau kebijakan criminal (criminal policy) merupakan bagian dari politik hukum pidana (criminal law policy). Kebijakan criminal merupakan cabang ilmu baru yang berobjekkan kejahatan dimana hukum pidana dan kriminologi telah lebih dahulu muncul sebelum kebijakan criminal ini.

Menurut Marc Ancel, hukum pidana modern terdiri atas hukum pidana (criminal law) yang merupakan penjelasan dan penerapan aturan positif dimana masyarakat memberikan reaksinya terhadap 
fenomena kejahatan. Kriminologi merupakan studi tentang fenomena kejahatan yang dipandang dari berbagai aspeknya dan kebijakan kriminal (penal policy) yang merupaka ilmu sekaligus seni dimana kegunaan praktis yang menjadi tujuan akhirnya., guna memungkinkan aturan-aturanhukum positif dirumuskan dengan lebih baik dan sebagai penunutun bagi pembuat hukum juga pengadilan dan lembaga pemasyarakatan yang membrikan efek praktis terhadap keputusan pengadilan (Zaidan, 2015: 99).

Kebijakan hukum pidana (penal policy) pada hakikatnya juga merupakan kebijakan hukum pidana (penal law enforcement policy). Kebijakan penegakan hukum pidana merupakan serangkaian proses yang terdiri dari tiga tahap kebijakan.Pertama, tahap kebijakan formulatif aatau tahap kebijakan legislative, yaitu tahap penyusunan/perumusan hukum pidana. Kedua tahap kebijakan yudikatif/aplikatif, yaitu tahap penerapan hukum pidana.Ketiga, tahap kebijakan eksekutif/administrasi.Yaitu tahap pelaksanaan/ eksekusi hokum pidana (Arif, 2015: 9). Dalam black law dictionary, Bryan A. Garner menyatakan bahwa kebijakan criminal/kebijakan hukumk pidana (criminal policy) meruapak cabang dari (ilmu) hukum pidana yang berkaitan dengan perlindungan terhdap kejahatan (the branch of criminal science concerned with protecting against crime). Frasa "berkaitan dengan" maksudnya adalah lebih menekankan kepada aspek perlindungan masyarakat terhadap kejahtaan melalui penegakan hokum (Zaidan, 2016: 124).

Muladi menambahkan kebijakan kriminal ialah usaha rasional dan terorganisir dari suatu masyarakat untuk menanggulangi kejahatan (Zaidan, 2016: 262), kebijakan criminal disisamping dapat dilakukan secara represif melalui system peradilan pidana (pendekatan penal) apat pula dilakukan dengan sarana non penal melalui perlbagai usaha pencegahan tanpa melibatkan system peradilan pidana, misalnya usaha penyehatan mental masyarakat, penyluhan hukum, pembaruan hukum data serta hukum administrasi, dan sebagainya. Menurut muladi, pencegahan kejahatan pada dasarnya merupakan tujuan utama dari kebijakan criminal. Selanjutnya, penulis berpendapat bahwa kebijakan hukum pidana merupakan kebijakan yang diambil 
oleh lembaga Negara yang mempunyai otoritas dalam membentuk, mengatur, dan mengimplementasikan produk perundang-undangan dengan tujuan untuk menertibkan dan mensejahterakan masyarakat atau warga Negara.

Sebagai badan atau pejabat pemerintahan yang memiliki tugas dan wewenang dalam membuat sebuah kebijakan pada kenyataannya dihadapkan pada pelbagai pilihan untuk menetapkan ketentuanketentuan hukum pidana yang lebih baik, sekaligus sebagai garis-garis kebijaksanaan dalam menentukan langkah penegakan hukum hukum pidana sebagai langkah awal atau usaha untuk mengkongkretkan aturan hukum yang telah dibuat tersebut. Kesepakatan antara pemerintah dan legislatif menghasilkan berbagai produk hukum sebagai bentuk "Kebijakan Negara" (State Policy) yang dituangkan dalam suatu produk Undang-Undang atau Peraturan Pemerintah. Pengganti Undang-Undang, serta peraturan pelaksanaanya yang harus diarahkan untuk kesejahteraan rakyat. sebagai bagian tujuan Negara sebagaimana yang tertuang dalam konstitusi (Darmono, 2018).

Kebijakan penggulangan kejahatan hukum pidana sebagai sarana utama, penetapan perbuatan yang dilarang dan diancam dengan ancaman sanksi merupakan bentuk penegakan hukum yang bersifat in abstracto, pembentuk undang-undang (badan legislasi) dapat menentukan perbuatan-perbuatan apa yan dilarang dan sanksi yang diancamkan apabila larangan itu dilanggar (on recht in actu) juga perbuatan-perbuatan apa yang berpotensi terjadi (on recht in potentie). Proses legislasi/formulasi merupakan tahap perencanaan awal yang sangat strategis dari proses penegakan hokum "in concreto", roeslan saleh pernah mengatakan bahwa undang-undang merupakan bagian dari suatu kebijaksanaan tertentu; ia tidak hanya alat untuk melaksanakan kebijaksanaan, tetapi juga menentukan, menggariskan atau merancangkan suatu kebijaksanaan (Saleh, 1984: 44-45).

Kebijakan criminal (criminal policy) biasanya menggunakan pendekatan kebijakan rasional, yang mana pendekatan rasioanal ini erat kaitannya dengan pendekatan yang berorientasi ekonomis dalam penggunaan hukum pidana. Pendekatan yang berorientasi ekonomis 
disini tidak hanya dimaksudkan untuk mempertimbangkan antara biaya atau ebban yang ditanggung masyarakat (dengan dibuat dan digunakannya hukum pidana) dengan hasil yang ingin dicapai, tetapi juga dalam arti mempertimbangkan efektifitas dari sanksi pidana itu sendiri. Sehubungan dengan hal ini, Ted honderich (2010: 46) berpendapat bahwa suatu pidana dapat disebut sebagai alat pencegah yang ekonomis (economical deterrents) apabila dipenuhi syarat-syarat sebagai berikut:

a. Pidana itu sungguh-sungguh mencegah

b. Pidana itu tidak menyebabkan timbulnya keadaan yang lebih berbahaya/merugikan daripada yang akan terjadi apabila pidana itu dikenakan

c. Tidak ada pidana lain yang dapat mencegah secara efektif dengan bahaya/kerugian yang lebih kecil.

Disisi lain, kebijakan menggunakan pendekatan nilai, yang mana dalam pendekatan ini menekankan pada nilai-nilai yang hendak ingin dicapai ataupun dilindungi oleh hukum pidana. Dengan kata lain pendekatan nilai ini melindungi kepentingan-kepentingan social yang memuat nilai-nilai yang hendak dilindungi, ditertibkan serta dipertahankan. Pidana hanya dibenarkan apabila ada kebutuhan yang berguna bagi masyarakat; pidana yang tidak diperlukan, tidak dapat dibenarkan dan berbahaya bagi masyarakat. Selain itu batas-batas sanksi pidana ditetapkan pula berdsar kepentingan-kepentingan ini dan nilai-nilai yang mewujudkannya.

Kebijakan criminal (criminal policy) tidak dapat dilepaskan sama sekali dari masalah nilai karena seperti dikatakan oleh Christiansen, the conception of problem crime and punishment is an essential part of the culture of any society. Begitu pula begitu pula menurut W. Clifford, the very foundation of any criminal justice system consist of the philosophy behind a given country. Terlebih bagi Indonesia yang berlandaskan nilai-nilai pancasila dan garis kebijakan pembangunan nasionalnya bertujuan membentuk manusia Indonesia seutuhnya. Apabila kebijakan hukum pidana/criminal akan digunakan sebagai sarana untukmencapai tujuan tersebut, maka pendekatan humanistic harus pula diperhatikan. Hal ini 
penting tidak hanya karena kejahatan itu pada hakikatnya merupakan masalah kemanusiaan, tetapi juga karena pada hakikatnya pidana itu sendiri mengandung unsur penderitaan yang dapat menyerang kepentingan atau nilai yang paling berharga bagi kehidupan manusia.

Dari uraian diatas dapatlah ditarik benang merah bahwa dalam melakukan kebijakan criminal (criminal policy) diperlukan pendekatan yang berorientasi pada kebijakan (policy oriented approach) yang lebih bersifat pragmatis dan rasional serta pendekatan yang berorientasi pada nilai(value judgment approach). Ruang lingkup kebijakan pidana sebenarnya lebih luas daripada pembaharuan hukum pidana. Kebijakan hukum pidana dilaksanakan melalui tahap-tahap konkretisasi/operasionalisasi/fungsionalisasi hukum pidana yang terdiri dari:

a. Tahap formulasi yaitu tahap penegakan hukum in abstracto oleh badan pembuat undang-undang. Tahap ini disebut dengan tahap kebijakan legislatif.

b. Tahap aplikasi yaitu tahap penerapan hukum pidana oleh aparat penegak hukum mulai dari kepo lisian sampai ke pengadilan. Tahap ini disebut dengan tahap kebijakan yudikatif.

c. Tahap eksekusi yaitu tahap pelaksanaan hukum pidana secara konkret oleh aparat-aparat pelaksanaan pidana. Tahap ini disebut tahap kebijakan eksekutif atau administratif.

Dalam rangka melindungi dan menciptakan kesejahteraan masyarakat, hukum pidana mempunyai posisi sentral untuk menyelesaikan konflik (kejahatan) yang terjadi. Masyarakat Indonesia yang heterogen, baik horizontal (suku, agama, ras) maupun vertical (perbedaan kekayaan, ilmu pengetahuan dan teknologi), pada hakikatnya dapat menjadi faktor kriminogen, terutama jika terjadi ketidakadilan dan diskriminasi dalam menangani masyarakat. Dengan demikian, hukum pidana menjadi penting perannya, sekarang dan di masa mendatang, bagi masyarakat sebagai control social untuk mencegah timbulnya disorder, khususnya sebagai pengendali kejahatan. Untuk menegakkan hukum pidana, maka harus ada keterpaduan dalam persepsi dan penanganan konflik yang timbul dari 
semua komponen hukum pidana, baik komponen structural, substansial, dan dukungan social. Pada komponen substansial yang bersifat normative dan normal seharusnya berpijak dan mengutamakan keadilan, kemudian kemanfaatan, dan selanjutnya pijakan terakhir adalah kepastian hukum. Selanjutnya, kebijakan hukum pidana terhdap tindak pidana cybercrime telah teraktualisasikan dalam Undang-Undang 11 Tahun 2008 yang mana telah diubah dengan Undang-Undang Nomor 19 Tahun 2016 tentang Informasi dan Transaksi Elektronik terutama dalam Passal 27 ayat (1) menyatakan bahwa "Setiap orang dengan sengaja dan tanpa hak mendistribusikan dan/atau mentransmisikan dan/atau membuat dapat diaksesnya Informasi Elektronik dan/atau Dokumen Elektronik yang memiliki muatan yang melanggar kesusilaan".

\section{Kedudukan Korban Cyber Pornography}

Sejak dulu kedudukan korban akibat dari suatu tindak pidana selalu ditempatkan pada posisi yang tidak menguntungkan, mengingat bahwa korban merupakan seseorang yang telah menderita kerugian sebagai akibat kejahatan dan atau rasa keadilannya secara langsung telah terganggu sebagai akibat pengalamannya sebagai sasaran kejahatan. Dalam hukum positif Indonesia masalah perlindungan korban sudah mendapat pengaturan meskipun sifatnya sangat sederhana dan parsial.

Kedudukan korban yang tidak mendapat tempat dalam proses peradilan pidana dikarenakan sistem peradilan pidana yang berlaku sekarang menganut keadilan retributif (retributive justice), penyelesaian perkara hanya semata-mata ditujukan untuk menjatuhkan sanksi kepada pelaku kejahatan tanpa mempertimbangkan aspek kerugian yang diderita korbar. Penjatuhan sanksi semata-mata untuk pembalasan terhadap pelaku tanpa memulihkan kerugian yang diderita oleh korban (Yulia, 2009: 240). Terabaikannya hak dan kepentingan korban tindak pidana pada tataran normatifperundang-undangan, pada gilirannya membawa konsekuensi terabai-kannya hak dan kepentingan korban dalam proses penyelesaian perkara pidanamelalui mekanisme sistem peradilan 
pidana. Kedudukan korban tindak pidana yang terbatas hanya sebagai saksi, jelas tidak memungkinkannya untuk menyuarakan as-pirasi mengenai hak dan kepentingannya sebagai korban yang telah menderita kerugianakibat perbuatan pelaku tindak pidana (Surbakti, 20111: 92).

Pengaturan terkait dengan korban bisa kita lihat dalam hukum pidana materiil maupun formil. Dalam hukum pidana materiil terlihat dalam pasal 14 huruf c KUHP dalam hal ini hakim akan menjatuhkan pidana bersayarat, ditentukan adanya syarat umum dan syarat khusus yanjg harus dipenuhi oleh terpidana selama dalam masa percobaannya harus mengganti segala atau sebagian kerugian yang ditimbulkan oleh perbuatannya (Sunarso, 2012: 53). Korban menurut Pasal 1 ayat (2) Undang-Undang Nomor 13 Tahun 2006 tentang Perlindungan Saksi dan Korban, yaitu: "Korban adalah seseorang yang mengalami penderitaan fisik, mental, dan/ atau kerugian ekonomi yang diakibatkan oleh suatu tindak pidana".

Berdasarkan penjabaran diatas, jelas bahwa korban kurang mempunyai daya tawar terhadap apa yang dialaminya dari akibat suatu tindak pidana selain menyerahkan setiap kepentingannya untuk diwakili oleh Negara. Apalagi terkait dengan kedudukan korban akibat dari tindakan cyber pornography tentu saja sangat rentan dan dirugikan secara materiil dan inmateriil, serta secara psikis akan terganggu pun juga nama baiknya juga ikut tercemar dan mendapat stigma negative dari masyarakat. Hal itu juga bisa dialami oleh para korban cyber pornography yang masih dalam tahap persidangan atas suatu tindak pidana yang dialaminya, apabila dalam proses persidangan ternyata korban dinyatakan tidak bersalah oleh majelis hakim dan berita-berita yang diakibatkan oleh cyber pornography tersebut yang tersebar di dunia maya secara jelas akan sangat merugikan korban. Hal itu disebabkan karena, teknologi intenet telah membawa materi pornografi yang dulu hanya bisa diakses melalui buku maupun video ke dalam dunia cyber yang luas (Engel, 2012: 61).

Cyber pornography sebenarmya sudah diatur dalam Pasal 4 Undang-Undang Nomor 44 Tahun 2008 tentang Pornografi yang 
menyatakan bahwa: "Setiap orang dilarang memproduksi, membuat, memperbanyak, menggandakan, menyebarluaskan, menyiarkan, mengimpor, mengekspor, menawarkan, memperjualbelikan, menyewakan, atau menyediakan pornografi yang secara eksplisit memuat:

a. Persenggamaan, termasuk persenggamaan yang menyimpang;

b. Kekerasan seksual;

c. Masturbasi atau onani;

d. Ketelanjangan atau tampilan yang mengesankan ketelanjangan;

e. Alat kelamin; atau

f. Pornograpi anak"

Selanjutnya, Pasal 27 ayat (1) Undang-Undang Nomor 19 Tahun 2016 perubahan atas Undang-Undang 11 Tahun 2008 tentang Informasi dan Transaksi Elektronik menyatakan bahwa : "Setiap Orang dengan sengaja dan tanpa hak mendistribusikan dan/atau mentransmisikan dan/atau membuat dapat diaksesnya Informasi Elektronik dan/atau Dokumen Elektronik yang memiliki muatan yang melanggar kesusilaan". Pasal 27 ayat (1) memiliki sanksi pidana yang ditentukan dalam Pasal 45 ayat (1), yang menyatakan bahwa:"Setiap orang yang memenuhi unsure sebagaimana dalam Pasal 27 ayat (1), ayat (2), ayat (3), atau ayat (4) dipidana dengan pidana penjara paling lama 6 (enam) tahun dan/atau denda paling banyak Rp. 1.000.000.000,00 (satu miliar rupiah)".

Konstruksi Pasal 27 ayat 1 diatas menjelaskan perkembangan modus kejahatan dan/atau pelanggaran dengan media computer atau internet (dalam bentuk informasi/dokumen elektronik). Hal tersebut sangatlah penting khususnya membantu para penegak hukum dalam memproses dan mengadili kasus-kasus yang telah menggunakan media infomasi elektronik untuk memuluskan kejahatan/pelanggaran yang dilakukan (Maskun, 2014:34). Setidaknya terdapat beberapa hal yang perlu diperhatikan dalam Pasal-Pasal tersebut, diantaranya dalam hal penetapan pelaku (subyek hukum). Pelaku yang dapat dijerat oleh ketentuan Pasal 27 ayat (1) di UU ITE adalah pihak yang mendistribusikan, mentransmisikan dan/atau memuat dapat 
diaksesnya informasi elektronik dan/atau dokumen elektronik yang memiliki muatan yang melanggar kesusilaan, sedangkan pihak yang memproduksi dan yang menerima distribusi dan transmisi tersebut tidak dapat terjerat dengan Pasal ini. Selain itu pihak yang mengakses muatan tersebut juga tidak dapat dipidana dengan pasal ini (Suhariyanto,2012: 162).

Seperti halnya dalam kasus penyebaran video porno antara Ariel Peterpan dengan Luna Maya dan Cut Tari. Dalam kasus tersebut, Ariel sebagai pembuat video tersebut, tidak dikenakan Pasal 27 ayat 1 UU ITE, Namun dikenakan Pasal 29 jo. Pasal 4 ayat (1) Undang-Undang Nomor 44 Tahun 2008 tentang Pornografi jo. Pasal 56 ke-2 KUHP (Machmud, 2012: 230). Baik Undang-Undang Pornografi dan Undang-Undang ITE dapat dipergunakan untuk menjerat pelaku kejahatan pornografi yang menggunakan media internet. Meski demikian, pasal 282 KUHP juga masih dapat digunakan untuk menjangkau pornografi di internet karena rumusan pasal tersebut yang cukup luas, ditambah lagi Pasal 44 Undang-Undang Pornografi menegaskan bahwa semua peraturan perundang-undangan yang mengatur atau berkaitan dengan tindak pidana pornografi dinyatakan tetap berlaku sepanjang tidak bertentangan dengan UU tersebut.

\section{Regulasi Prinsip Right To Be Forgoten}

Berangkat dari pemenuhan terhadap hak asasi manusia maupun dari asas yang terkandung dalam Undang-Undang Nomor 19 Tahun 2016 perubahan atas Undang-Undang 11 Tahun 2008 tentang Informasi dan Transaksi Elektronik khususnya asas kehati-hatian dan asas iktikad baik, maka dirasa perlu untuk memberikan perlindungan dan kepastian hukum bagi korban atas tindakan atau perbuatan cyber pornography yang terjadi di dunia maya. Perkembangan cyber pornography sudah sedemikian kompleks, dimana materi muatan (konten) yang semakin eksplisit (vulgar) dan menjijikkan, sehingga tidak sedikit dari kalangan pengguna internet dapat mengakses konten-konten tersebut.

Bahwa penerapan right to be forgotten di Indonesia akan berbeda dengan negara lain. Penghapusan konten di Uni Eropa atau Rusia atau 
negara lainnya yang menerapkan hanya dilakukan sebatas dalam mesin pencari (search engine), di Indonesia nantinya tidak akan seperti itu Penghapusan konten yang dianggap tidak relevan berdasarkan penetapan pengadilan langsung dilakukan oleh penyelenggara sistem elektronik yang memegang kendali langsung atas suatu konten tertentu (www.hukumonline.com).

Hak untuk dilupakan (right to be forgoten) merupakan hak seseorang agar data (video, gambar, dokumen, dll) yang beredar di dunia maya dapat dilupakan atau dihapus apabila dalam persidangan dipengadilan terdakwa tidak terbukti bersalah. Sejalan dengan hal itu, pemerintah dan DPR memasukkan prinsip right to be forgoten dalam Undang-Undang Nomor 19 Tahun 2016 perubahan atas UndangUndang 11 Tahun 2008 tentang Informasi dan Transaksi Elektronik Pasal 26 ayat (3) dan (4) yang menyatakan bahwa:

a. Setiap Penyelenggara Sistem Elektronik wajib menghapus Informasi Elektronik yang tidak relevan yang berada di bawah kendalinya atas permintaan orang yang bersangkutan berdasarkan penetapan pengadilan.

b. Setiap Penyelenggara Sistem Elektronik wajib menyediakan mekanisme penghapusan Informasi Elektronik yang sudah tidak relevan.

Konsekuensi yuridis atas dimasukkan prinsip right to be forgoten dalam perubahan UU ITE tersebut haruslah diatur sedemikian rupa dalam bentuk Peraturan Pemerintah selaku pelaksana teknis dari UU ITE. Hal itu perlu dilakukan mengingat bahwa prinsip right to be forgoten beririsan dengan UU Pers dimana seseroang juga mempunyai hak untuk memperoleh informasi, dengan begitu pengaturan prinsip right to be forgoten perlu diaktualisasikan terhadap kasus-kasus tertentu seperti halnya korban cyber pornography bukan untuk diterapkan terhadap kasus korupsi atau kasus lain yang ada sangkut pautnya dengan kerugia Negara.

Ketentuan Pasal 26 (3) UUITE intinya mengatur tentang penggunaan informasi sebagai data pribadi seseorang sebagai hak untuk menggugat atas kerugian yang timbul untuk menghapus 
informasi yang tidak relevan lagi berdasarkan penetapan pengadilan, olehnya masyarakat masih mengharapkan adanya aturan lebih konkrit tentang tindakan cyber pornography yang harus dilakukan pemerintah untuk mengatasi dilema sosial ini. Dengan demikian regulasi terkait dengan prinsip right to be forgoten perlu dipertegas melalui Peraturan Pemerintah agar dapat terlaksana serta memperjelas tindak pidana apa saja yang dapat menggunakan right to be forgoten terlebih lagi terhadap kejahatan cyber pornography. Dalam pemanfaatan Teknologi Informasi, perlindungan data pribadi merupakan salah satu bagian dari hak pribadi (privacy rights). Hak pribadi mengandung pengertian sebagai berikut:

a. Hak pribadi merupakan hak untuk menikmati kehidupan pribadi dan bebas dari segala macam gangguan.

b. Hak pribadi merupakan hak untuk dapat berkomunikasi dengan Orang lain tanpa tindakan mematamatai.

c. Hak pribadi merupakan hak untuk mengawasi akses informasi tentang kehidupan pribadi dan data seseorang

Ada dari sebagaian kalangan menentang dimasukkannya prinsip right to be forgoten dalam perubahan UU ITE yang baru, mereka beralasan bahwa dengan adanya prinsip right to be forgoten tersebut bisa saja disalahgunakan oleh para koruptor atau seseorang yang melakukan tindak pidana narkotika dan kejahatan yang lain untuk data maupun informasinya terkait dengan kejahatannya dapat dihilangkan dari mesin pencarian di google. Lebih lanjut, adanya prinsip right to be forgoten bisa saja membatasi akses dari masyarakat untuk memperoleh informasi ataupun data yang sedemikian rupa pun juga dapat membatasi kebebasan pers dalam memberikan layanan informasi kepada masyarakat.

Terlepas dari berbagai pro kontra dari dimasukkannya norma prinsip right to be forgoten dalam perubahan UU ITE yang baru, dalam hal kasus tertentu seperti kejahatan cyber pornography sangat penting untuk diberlakukan demi melindungi hak-hak korban serta melindungi masyarakat dari konten-konten yang melanggar norma kesusilaan. Prinsip right to be forgoten bagi korban cyber pornography 
perlu diberlakukan karena cyber pornography merupakan tindakan penyebarluasan konten atau materi yang memuat seperti gambar,video porno yang sudah barang tentu menyalahi norma kesusilaan ke dunia maya melalui teknologi internet. Penyebarlusan konten tersebut tentu saja bisa diakses oleh semua orang dan kalangan di perlbagai penjuru dunia karena memang sejatinya dunia maya tidak mengenal batas territorial dan melampaui batas dari suatu Negara. Ditegaskan oleh Aloysius bahwa, kejahatan ancaman merebaknya kejahatan berbasis teknologi, khususnya kejahatan mayantara yang tidak mengenal batas terituorial (borderless) Negara, merupakan persoalan yang sangat serius sehingga perlu dikendalikan dengan system hukum yang sesuai termasuk system hukum pidana sebagai ultimum remedium (Wisnubroto, 2011: 6).

Sudah sepantasnya Pemberlakuan hak melupakan (right to be forgotten) bagi korban cyber pornography dalam sebuah pemberitaan hanya dianggap bahwa fakta yang diberitakan tersebut adalah realitas kemasyarakatan yang terjadi sepantasnya untuk dilupakan dari pemberitaan yang tidak lagi dianggap relevan pada suatu waktu, dan dijadikan sebagai bahan pembelajaran bagi masyarakat lain agar memiliki sikap kewaspadaan dan tidak menjadi korban terhadap tindakan cyber pornography atau prilaku yang dapat berakibat hukum dan tidak mampu mendapatkan penetapan dari pengadilan. Namun sesungguhnya lebih daripada itu, bahwa hak melupakan juga dapat diartikan kewajiban untuk dilampirkan dalam sebuah pemberitaan secara implisit yang menekankan bahwa seseorang dapat dimaafkan atas kesalahan dimasa lampau dan yang telah melewati proses sanksi hukuman (memberikan hak melupakan kepada seseorang), serta wajib diberikan kesempatan untuk mengembangkan diri melalui kepercayaan publik yang ditanamkan melalui pemberitaan itu pula.

\section{SIMPULAN}

Prinsip hak untuk dilupakan (right to be forgotten) perlu diberlakukan terhadap korban cyber pornography dan dikonkretkan melalui peraturan pemerintah sebagai peraturan pelaksana dari Pasal 26 ayat (3) dan (4) UU ITE agar hak-hak bagi setiap korban untuk terbebas dari setiap 
stigma negative ataupun sebagai cara untuk membersihkan namanya dari pemberitaan cyber pornography yang sudah terlanjur meluas di media social dengan penetapan pengadilan. Tentunya prinsip ini sangat didambakan oleh setiap korban dari cyber pornography untuk dapat menjalani kehidupannya dimasa yang akan datang tanpa perlu terbebani dengan persoalan masa lalunya.

\section{DAFTAR REFERENSI}

Agus Raharjo, Cyber Crime Pemahaman dan Upaya Pencegahan Kejahatan Berteknologi, Bandung :Citra Aditya Bakti, 2002.

Abdul Wahid dan Muhammad Labib, Kejahatan Mayantara (cybercrime), Bandung: Refika Aditama, 2010.

Al. Wisnubroto, Konsep Hukum Pidana Telematika, cetakan pertama Yogyakarta: Universitas Atma Jaya Yogyakarta, 2011.

Budi Suhariyanto, Tindak Pidana Teknologi Informasi (Cyber Crime): Urgensi

Pengaturan dan Celah hukumnya, Jakarta: Rajawali Pers, 2012.

Departemen Pendidikan Nasional,"Kamus Besar Bahasa Indonesia Pusat

Bahasa", edisi Keempat Jakarta : PT Gramedia Pustaka Utama, 2011.

Maskun, Kejahatan Siber Cyber Crime; Suatu Pengantar, Jakrta: Kencana, 2014.

Rena Yulia,"Restorative Justice Sebagai Alternatif Perlindungan Hukum

Terhadap Korban Kekerasan Dalam Rumah Tangga", Jurnal Hukum dan Pembangunan, Edisi No. 2 (2009).

Syarif Hidayatullah dan Zulfikar S Dharmawan, Islam Virtual Keberadaan Dunia Islam di Internet, Ciputat: Mifta, 2004.

Sigid Suseno, Yurisdiksi Tindak pidana Siber, Bandung: Refika Aditama, 2012. Syahrul Machmud, Penerapan Undang-Undang Pornografi Pada Kasus Ariel Peterpan, Yogyakarta: Graha Ilmu, 2012.

Siswanto Sunarso, Viktimologi Dalam Sistem Peradilan Pidana, cetakan pertama, Jakrta: Sinar Grafika, 2012.

Ventje Jeremias Lewi Engel. Upaya Melindungi Anak-Anak Dari Pornografi di Internet, Jurnal Sosioteknologi, Edisi 25 Tahun (2012).

Harol Agusto Manurung, "Analisis Yurisdis Kejahatan Pornografi (Cyberporn) sebagai kejahatan transnasional" Diponegoro Law Journal, Edisi No. 3 Vol 5 (2016). 
Natangsa Surbakti,"Mediasi Penal Sebagai Terobosan Alternatif Perlindungan Hak Korban Tindak Pidana", Jurnal Ilmu Hukum, Edisi No. 1 Vol. 14 (2011).

http://www.hukumonline.com/berita/baca/lt586214ee33609/ini-bedanya-ko nsep-iright-to-be-forgotten-i-di-indonesia-dengan-negara-lain. diakses pada tanggal 1 September 2018 